$\mathrm{ZnCl}_{2}$ ). Typical yields obtained were $1 \mathrm{mg}$ of $>90 \%$ pure T7EX556 per liter of starting culture. 13. F. Payvar et al., Cell 35, 381 (1983)

14. W. C. Soeller et al., Genes Dev. 2, 68 (1988).

15. U. Heberlein and R. Tjian, Nature 331, 410 (1988)

16. J. LaBaer, thesis, University of California, San Francisco (1989).

17. R. Schüle et al., Science 242, 1418 (1988)

18. DNA fragments without GREs were inserted into the Xba I site (see Fig. 2) of $-33 \mathrm{GRE}_{6}$, displacing the GRE cassette to $-262,-366$, and -1069 bp from the start of transcription. Weak receptor-mediated activation was detected when GREs were situated at -262 , but no effect was observed from the more distal sites.

19. A. Sergeant, D. Bohman, H. Zentgraf, H. Weihler, W. Keller, J. Mol. Biol. 180, 577 (1984); P. Sassone-Corsi, A. Wilderman, P. Chambon, Nature 313, 458 (1985); H. R. Scholer and P. Gruss, EMBO J. 4, 3005 (1985); Y.-S. Lin, M. F. Carey, M. Ptashne, M. R. Green, Cell 54, 659 (1988).

20. L. P. Freedman, unpublished.
21. A. Fire, U. Samuels, P. A. Sharp, J. Biol. Chem. 259, 2509 (1984); D. K. Hawley and R. G Roeder, ibid. 262, 3452 (1987).

22. B. Corthésy et al., Science 239, 1137 (1988).

23. S. K. Yoshinaga and L. P. Freedman, unpublished.

24. K. A. Jones et al., Cell 42, 559 (1985).

25. C. Scheidereit and M. Beato, Proc. Natl. Acad. Sci. U.S.A. 81, 3029 (1984).

26. H. M. Jantzen et al., Cell 49, 29 (1987)

27. We thank W. Soeller for embryo extracts and discus sions; M. Biggin, B. England, D. Granner, J. La Baer, and D. Picard for DNA reagents; $S$. Johnson and R. Myers for critical readings of the manuscript; and K. Mulherin and B. Maler for preparation of the text and figures, respectively. Supported by grants from the National Institutes of Health and the National Science Foundation; postdoctoral support was from the American Cancer Society, California Division (S.K.Y.), and from the Bank of AmericaGiannini Foundation (L.P.F.).

18 April 1989; accepted 2 June 1989

\title{
Monoclonal Antibody-Mediated Tumor Regression by Induction of Apoptosis
}

\author{
Bernhard C. Trauth, Christiane Klas, Anke M. J. Peters, \\ Siegfried Matzku, Peter Möller, Werner Falk, \\ Klaus-Michael Debatin, Peter H. Krammer*
}

To characterize cell surface molecules involved in control of growth of malignant lymphocytes, monoclonal antibodies were raised against the human $B$ lymphoblast cell line SKW6.4. One monoclonal antibody, anti-APO-1, reacted with a 52-kilodalton antigen (APO-1) on a set of activated human lymphocytes, on malignant human lymphocyte lines, and on some patient-derived leukemic cells. Nanogram quantities of anti-APO-1 completely blocked proliferation of cells bearing APO-1 in vitro in a manner characteristic of a process called programmed cell death or apoptosis. Cell death was preceded by changes in cell morphology and fragmentation of DNA. This process was distinct from antibody- and complement-dependent cell lysis and was mediated by the antibody alone. A single intravenous injection of anti-APO-1 into $n u$ / $n u$ mice carrying a xenotransplant of a human B cell tumor induced regression of this tumor within a few days. Histological thin sections of the regressing tumor showed that anti-APO-1 was able to induce apoptosis in vivo. Thus, induction of apoptosis as a consequence of a signal mediated through cell surface molecules like APO-1 may be a useful therapeutic approach in treatment of malignancy.

$\mathrm{C}$ ELL SURFACE MOLECULES ARE CRUcial in lymphocyte growth control. Such molecules may function as receptors for growth-stimulating cytokines or be associated with receptors and transmit signals essential for growth regulation. Receptor blockade or removal of the stimulating cytokines can lead to decreased lymphocyte growth. Withdrawal of interleukins slow human lymphocyte growth and finally leads to a characteristic form of cell death called "programmed cell death" or apoptosis (1). Apoptosis is the most common form of eukaryotic cell death and occurs in embryogenesis, metamorphosis, tissue atrophy, and tumor regression (2). It is also induced by cytotoxic $\mathrm{T}$ lymphocytes and natural killer and killer cells; by cytokines like tumor necrosis factor (TNF) and lymphotoxin (LT); and by glucocorticoids $(1,2)$. The most characteristic signs of apoptosis are segmentation of the nucleus, condensation of the cytoplasm, membrane blebbing, and DNA fragmentation into multimers of about 180 base pairs (called a "DNA ladder") $(1,2)$. To analyze mechanisms of lymphocyte growth control and to interfere with the replication of lymphoid tumor cells we raised monoclonal antibodies (MAbs) against cell surface molecules involved in these processes.

We found one MAb (anti-APO-1) that blocks growth and induces apoptosis of SKW6.4 cells (3). Anti-APO-1 (IgG3, K, $K_{\mathrm{D}}=1.9 \times 10^{-10}$ ) bound to approximately $4 \times 10^{4}$ sites on the surface of SKW6.4 cells (4). It specifically immunoprecipitated an endogenously synthesized protein antigen (APO-1) from SKW6.4 cells which, under reducing conditions, was observed on SDS-
Fig. 1. Molecular weight of the cell surface antigen APO-1: immunoprecipitation of biosynthetically labeled APO-1 from the surface of SKW6.4 cells with either isotype-matched control MAb (left lane) or antiAPO-1 (right lane). The numbers on the left margin indicate the positions of the size markers. Cells $\left(3 \times 10^{6}\right)$ were labeled with $60 \mu \mathrm{Ci}$ of ${ }^{75}$ Se-labeled methionine (Amersham, Braunschweig, FRG) in $6 \mathrm{ml}$ of methionine-free culture medium (Biochrom, Berlin) for $\mathbf{4 8}$ hours. After washing, the cells were incubated in either control MAb or anti-APO-1 $(1 \mu \mathrm{g} / \mathrm{ml})$ at $4^{\circ} \mathrm{C}$ for $45 \mathrm{~min}$. The cells were washed and resuspended in lysis buffer

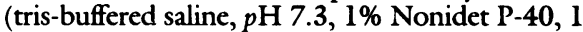
$\mathrm{m} M$ phenylmethylsulfonyl fluoride, $0.1 \%$ aprotinin) at room temperature for $30 \mathrm{~min}$. The lysates were centrifuged and supernatants were incubated with protein A-Sepharose beads (Pharmacia, Uppsala, Sweden) at $4^{\circ} \mathrm{C}$ for 1 hour. The immune complexes were washed four times with

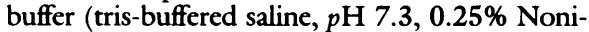
det P-40) and resuspended in SDS-PAGE sample buffer containing 5\% SDS and 5\% 2-mercaptoethanol. The samples were heated to $95^{\circ} \mathrm{C}$, centrifuged, and counts per minute of the supernatants were determined in a $\gamma$-counter. A total of 15,000 cpm were loaded in each lane and analyzed by a 10\% SDS-PAGE (18). The gel was dried and subjected to autoradiography.

polyacrylamide gel electrophoresis (SDSPAGE) as a main band of $52 \mathrm{kD}$ (Fig. 1). Apart from actin $(43 \mathrm{kD})$, which was nonspecifically precipitated with IgG3, antiAPO-1 specifically immunoprecipitated a minor band of $25 \mathrm{kD}$. This $25-\mathrm{kD}$ protein might either represent a degradation product or be noncovalently associated with the $52-\mathrm{kD}$ protein.

There are two major modes of death in nucleated eukaryotic cells. Necrosis as a result, for example, of complement attack is characterized by swelling of the cells and rupture of the plasma membrane caused by an increase in permeability. Cells that undergo apoptosis, however, show a different biochemical and morphological pattern (2). This pattern corresponds to the one induced by anti-APO-1: condensation of the cytoplasm, membrane blebbing (Fig. 2a), and endonuclease-induced DNA fragmentation (5) into multimers of approximately $180 \mathrm{bp}$

B. C. Trauth, C. Klas, A. M. J. Peters, W. Falk, P. H Krammer, Institute for Immunology and Genetics, German Cancer Research Center, Heidelberg, Federal Republic of Germany.

S. Matzku, Institute for Radiology and Pathophysiology, German Cancer Research Center, Heidelberg, Federal Republic of Germany.

P. Möller, Institute for Pathology of the University of Heidelberg, Federal Republic of Germany.

K.-M. Debatin, Oncology/Immunology Section, University Children's Hospital, Heidelberg, Federal Republic of Germany.

*To whom correspondence should be addressed: 
(Fig. 2b). Affinity-purified anti-APO-1 induced growth retardation and cell death (Fig. 2c), which was not observed with either an isotype-matched, control MAb (FII20) [anti-MHC (major histocompatability complex) class I antigens] or the nonbinding MAb FII23. Abrogation of $\left[{ }^{3} \mathrm{H}\right]$ thymidine incorporation along with increased trypan blue uptake into dead cells were observed, and growth of $10^{4} \mathrm{SKW6.4}$ cells in $200-\mu$ l cultures was blocked by more than $95 \%$ by an anti-APO-l concentration of only $10 \mathrm{ng} / \mathrm{ml}$ (Fig. 2c). The specificity of cell death induced by anti-APO-l becomes evident from the fact that the following additional control MAbs were inactive for induction of apoptosis: 18 nonbinding and 9 binding MAbs of the IgG3 isotype (tested by immunofluorescence on SKW6.4 cells) and a panel of MAbs directed against known antigens on the cell surface of SKW6.4 cells including CD19, CD20, CD22, MHC class

A

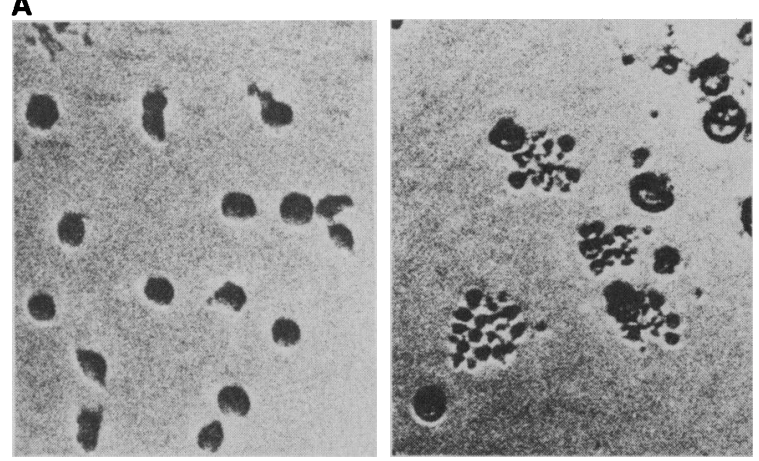

Fig. 2. Induction of growth inhibition and apoptosis by antiAPO-1. (A) The T cell line CCRF-CEM.S2 (19) was cultured in the presence of purified $\mathrm{MAb}(1 \mu \mathrm{g} / \mathrm{ml})$ in a microtiter plate for 2 hours before photography (left panel control MAb 13Bl; right panel anti-APO-1). (B) CCRF-CEM.S2 cells $\left(10^{6}\right.$ per milliliter) were incubated with MAb $(1 \mu \mathrm{g} / \mathrm{ml})$ in culture medium at $37^{\circ} \mathrm{C}$. At various times, aliquots of $10^{6}$ cells were removed and DNA was prepared. M, marker; I, control MAb I3B 1 for 2 hours; lanes 3 to 7 , anti-APO-1 for the times indicated. (C) SKW6.4 cells were either incubated with the isotype-matched control MAb FII20 ( $\square$ ), FII23 (nonbinding MAb) (O), or anti-APO-1 (O) in microcultures for 24 hours before labeling with $\left[{ }^{3} \mathrm{H}\right]$ thymidine for a further 4 hours. The data represent the mean of duplicate cultures with a variation of less than $5 \%$. The cells were cultured in RPMI 1640 medium (Gibco, Grand Island, New York), supplemented with $2 \mathrm{mM}$ Lglutamine, streptomycin $(100 \mu \mathrm{g} / \mathrm{ml})$, penicillin $(100 \mathrm{U} / \mathrm{ml}), 20$

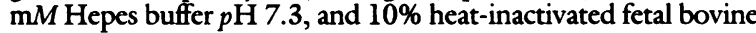
serum (Conco Lab-Division, Wiesbaden, FRG). For microcultures, $1 \times 10^{4}$ cells per well were cultured in duplicates in flatbottom 96-well microtiter plates (Tecnomara, Fernwald, FRG) ( $200 \mu \mathrm{l}$ final volume per well). After 24 hours, the cells were labeled with $0.5 \mu \mathrm{Ci}$ of $\left[{ }^{3} \mathrm{H}\right]$ thymidine (Amersham, Braunschweig, FRG) for 4 hours. Before harvesting, the microcultures were examined by microscopic inspection. DNA fragmentation $1 \times 10^{6}$ cells were washed with cold phosphate-buffered saline and disrupted with NTE buffer, $p \mathrm{H} 8(100 \mathrm{mM} \mathrm{NaCl}, 10 \mathrm{mM}$ tris, $1 \mathrm{~m} M$ EDTA) containing $1 \%$ SDS and proteinase $\mathrm{K}(0.2 \mathrm{mg} / \mathrm{ml})$. After incubation for 24 hours at $37^{\circ} \mathrm{C}$, samples were extracted twice with phenol plus chloroform $(1: 1, v / v)$ and precipitated by ethanol. The DNA was dissolved in $38 \mu \mathrm{l}$ of NTE buffer and digested with ribonuclease $(1 \mathrm{mg} / \mathrm{ml})$ for $30 \mathrm{~min}$ at $37^{\circ} \mathrm{C}$. To each sample $10 \mu \mathrm{l}$ of loading buffer containing 15\% Ficoll 400 (Pharmacia, Uppsala, Sweden), 0.5\% SDS, $50 \mathrm{mM}$ EDTA, $0.05 \%$ bromophenol blue, $0.05 \%$ xylene cyanol in TBE buffer ( $2 \mathrm{~m} M$ EDTA, $89 \mathrm{~m} M$ boric acid, 89 $\mathrm{m} M$ tris, $p \mathrm{H} \mathrm{8.4)}$ were added. The mixture was loaded onto a $1 \%$ agarose gel and stained after electrophoresis with ethidium bromide $(0.5 \mu \mathrm{g} / \mathrm{ml})$. The size marker was Hind III + Eco RI-digested $\lambda$ DNA.

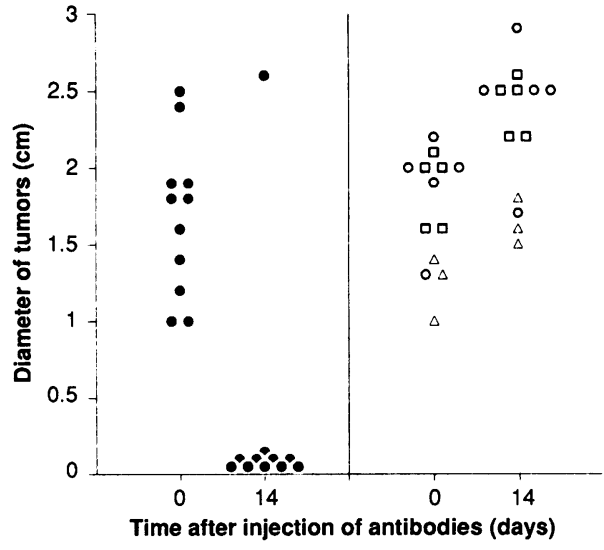

Fig. 3. Anti-APO-1-induced regression of the EBV-negative Burkitt-like lymphoma BJAB in $n u / n u$ mice. BJAB cells $\left(4 \times 10^{7}\right)$ were injected subcutaneously into the left flank of $n u / n u$ mice. After 5 weeks (day 0 ) the mice were injected with $500 \mu \mathrm{g}$ of MAb into the tail vein. Control MAb FII20 (口); FII23 (O); I3Bl $(\triangle)$; and anti-APO$1(0)$. Fourteen days later the size of the tumors was measured at the base of the tumor; the tumors from individual mice are represented by dots.

lymphoid $\mathrm{B}$ and $\mathrm{T}$ cell lines and was not found on a gibbon or mouse $\mathrm{T}$ cell line or a human monocytic cell line (Table 1). AntiAPO-1 blocked proliferation of the APO-1positive cell lines listed in Table 1 via induction of apoptosis, and formation of a DNA ladder was observed in each case (9). Expression of APO-1 was not restricted to cell lines in vitro but could be found on leukemic cells freshly isolated from patients (Table 1). Since APO-1 was not found on all leukemic cells it may be possible that anti-APO-1 defines a subpopulation of leukemias.

We also screened human $B$ and $T$ cells for expression of APO-1. We did not detect APO-1 on resting B cells. However, APO-1 was expressed on activated B cells (Table 1 ) and IgM secretion was reduced approximately fourfold by 3 days of treatment with anti-APO-1 (10). Peripheral resting T cells did not express APO-l. Activated T cells, however, expressed APO-1 and anti-APO1-induced apoptosis and growth inhibition of these cells (Table 1). Thus, our data suggest that APO-1 is a species-specific antigen expressed on activated or malignant lymphocytes.

The striking effect of anti-APO-1 in vitro prompted us to test its effect on tumor growth in vivo. Although the Epstein-Barr virus (EBV)-negative, Burkitt-like lymphoma BJAB was the least sensitive to antiAPO-1 of the B cell panel in Table 1 and expressed only approximately $1.5 \times 10^{4}$ APO-l epitopes per cell (4), we selected $B J A B$ for our in vivo experiments. The reason for this choice was that only $B J A B$ grew to large tumor masses in unirradiated $n u / n u$ mice. Five weeks after injection of 
Fig. 4. Localization of antiAPO-1 in xenografts of BJAB in $n u / n u$ mice and induction of apoptosis of the tumor. (A) Upper row: uptake of ${ }^{125}$ I-labeled $\mathrm{MAb}$ anti-APO-1 $(50 \mu \mathrm{g}, 50$ $\mu \mathrm{Ci}$ per mouse) in the tumor at 12 hours (1), 48 hours (2), and 96 hours (3) after intravenous injection of the MAb. Lower row: uptake of ${ }^{125}$ I-labeled MAb anti-APO-1 $(500 \mu \mathrm{g}$, as used for therapy; $50 \mu \mathrm{Ci}$ per mouse) (4) and FII20 (control $M A b$, binding to BJAB; $50 \mu \mathrm{g}$, $50 \mu \mathrm{Ci}$ per mouse) (5) and ${ }^{125} \mathrm{I}$ -

A

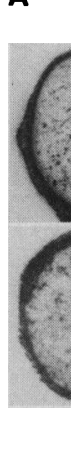

1

12

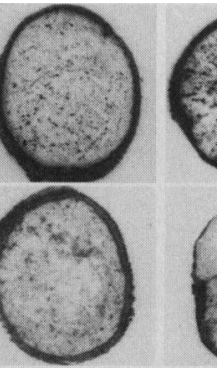

4

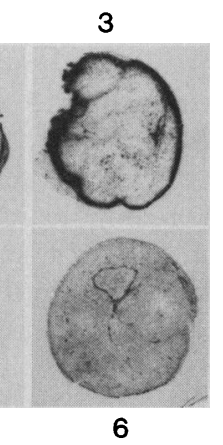

B

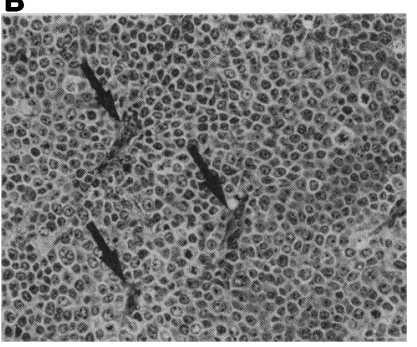

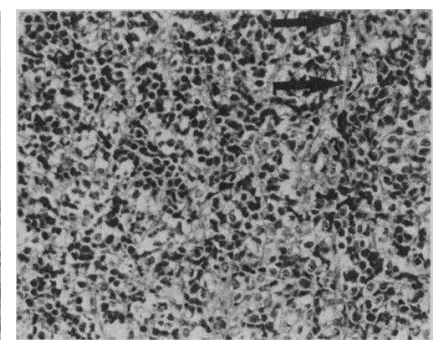

labeled FII23 (control MAb, nonbinding to BJAB; $50 \mu \mathrm{g}, 50 \mu \mathrm{Ci}$ per mouse) (6) in 48 hours, respectively. (B) Ten days after intravenous injection of $500 \mu \mathrm{g}$ of $\mathrm{MAb}$ per mouse the remaining tumor tissue was removed and fixed with formalin. Paraffin sections of the tumor were stained with haematoxylin/eosin. Left panel, tumor after treatment with control MAb FII20; right panel, tumor after treatment with anti-APO-1. Arrows

indicate host vessels. Final magnification, $\times 92$. MAbs were radioiodinated according to the IODO-Gen method (4). Labeled MAbs were injected into the tail vein and animals were killed by ether anesthesia at the predetermined time points. The tumors were excised and embedded in methylcellulose and $20-\mu \mathrm{m}$ cryotome sections were prepared. Lyophilized sections were placed on a Kodak X-omat AR film for autoradiography.
BJAB cells the $n u / n u$ mice carried tumors with a diameter of approximately 1.0 to 2.5 $\mathrm{cm}$ (Fig. 3). These mice were injected intravenously with purified anti-APO-l $(500 \mu \mathrm{g}$ per mouse) or the same quantities of various isotype-matched control antibodies (FII20, anti-MHC class I antigens, recognizing $5.8 \times 10^{5}$ sites per cell; or one of the two nonbinding MAbs FII23 and I3B1). As a control we also injected anti-APO-1 (500 $\mu \mathrm{g}$ per mouse) into three $n u / n u$ mice carrying the APO-1-negative B cell tumor OCI.LYl with tumor diameters of $1.5,1.8$, and $3.4 \mathrm{~cm}$, respectively (11) (see also Table 1). Two days after anti-APO-l injection, a whitish discoloration of the BJAB tumors was observed that was followed by rapid tumor regression. Macroscopic tumor regression was seen in 10 of 11 treated mice within less than 14 days. The control antibodies had no effect (Fig. 3). In addition, no tumor regression was observed in the mice carrying OCI.LYl, as expected.

To demonstrate proper localization and enrichment of the injected antibodies, labeled MAbs were visualized by autoradiography of sections of the BJAB tumor tissue (Fig. 4a). These autoradiographs showed a pronounced binding of anti-APO-l in the periphery but only sparse accumulation in the center of the tumor. The binding control MAb FII20 showed a qualitatively similar binding pattern. There was no localization of the nonbinding control MAb FII23 above background. Furthermore, paired label experiments (12) with labeled antiAPO-1 and FII23 revealed that the specific enrichment of anti-APO-1 over FII23 in the tumor was four- and sixfold after 48 and 96 hours, respectively.

The main purpose of our experiments was to assess whether anti-APO-l can also act in vivo. Therefore, the tumor-bearing mice only received one intravenous injection of anti-APO-l at a dose in the range used in
Table 1. Reactivity of anti-APO-1 with different cells.

\begin{tabular}{|c|c|c|c|c|c|}
\hline \multicolumn{2}{|c|}{ Cells* } & \multirow{2}{*}{$\begin{array}{l}\text { Cells } \\
\text { positive } \\
\text { for } \\
\text { APO-1 } \\
(\%) \dagger\end{array}$} & \multirow{2}{*}{$\begin{array}{c}\text { Relative } \\
\text { fluorescence } \\
\text { intensity } \\
\text { (anti-APO-1/ } \\
\text { control) }\end{array}$} & \multicolumn{2}{|c|}{$\begin{array}{c}\text { Effects of MAbs on } \\
{\left[{ }^{3} \mathrm{H}\right] \text { thymidine uptake }} \\
\left(10^{3} \mathrm{cpm}\right) \ddagger\end{array}$} \\
\hline Type & Designation & & & Control & Anti-APO-1 \\
\hline \multicolumn{6}{|c|}{ Malignant cell lines } \\
\hline Hu B cells & $\begin{array}{l}\text { SKW6.4 } \\
\text { CESS } \\
\text { BJAB } \\
\text { OCI.LY1 }\end{array}$ & $\begin{array}{r}98 \\
95 \\
80 \\
0\end{array}$ & $\begin{array}{c}11.1 \\
12.0 \\
2.1 \\
1\end{array}$ & $\begin{array}{l}30.0 \\
23.0 \\
70.0 \\
14.5\end{array}$ & $\begin{array}{c}0.02 \\
0.1 \\
7.0 \\
15.8\end{array}$ \\
\hline Hu T cells & $\begin{array}{l}\text { Jurkat } \\
\text { Molt } \\
\text { CCRF-CEM }\end{array}$ & $\begin{array}{l}83 \\
91 \\
64\end{array}$ & $\begin{array}{l}2.3 \\
2.4 \\
1.9\end{array}$ & $\begin{array}{l}20.3 \\
35.7 \\
16.2\end{array}$ & $\begin{array}{l}8.1 \\
0.6 \\
0.5\end{array}$ \\
\hline $\begin{array}{l}\text { Hu myeloid cells } \\
\text { Gibbon T cells } \\
\text { Mouse T cells }\end{array}$ & $\begin{array}{l}\text { U937 } \\
\text { MLA } 144 \\
\text { EL4 }\end{array}$ & $\begin{array}{c}\mathbf{5} \\
\mathbf{0} \\
\mathbf{0} \\
\text { ikemic cell. }\end{array}$ & $\begin{array}{c}0.97 \\
0.96 \\
1 \\
n \text { patients } \$\end{array}$ & $\begin{array}{l}62.2 \\
34.3 \\
44.8\end{array}$ & $\begin{array}{l}60.5 \\
35.0 \\
45.3\end{array}$ \\
\hline $\begin{array}{l}\text { Pre T-ALL } \\
\text { T-ALL } \\
\text { Common ALL }\end{array}$ & $\begin{array}{l}\text { B.M. } \\
\text { D.A. } \\
\text { W.N. }\end{array}$ & $\begin{array}{l}54 \\
53 \\
72 \\
\text { mal hum }\end{array}$ & $\begin{array}{r}4.4 \\
3.2 \\
5.0 \\
\text { mphocytes }\end{array}$ & & \\
\hline $\mathrm{T}$ cells $\|$ & $\begin{array}{l}\text { Resting } \\
\text { Activated }\end{array}$ & $\begin{array}{r}3 \\
89\end{array}$ & $\begin{array}{l}1.36 \\
7.4\end{array}$ & 22.4 & 0.23 \\
\hline B cellsף & $\begin{array}{l}\text { Resting } \\
\text { Activated }\end{array}$ & $\begin{array}{r}0 \\
91\end{array}$ & $\begin{array}{l}0.9 \\
1.1\end{array}$ & & \\
\hline
\end{tabular}

*Hu, human; ALL, acute lymphocytic leukemia.

tAliquots of $10^{6}$ cells were incubated at $4^{\circ} \mathrm{C}$ in $100 \mu \mathrm{l}$ of medium with control MAb (FII23 or I3B1) or anti-APO- 1 for $30 \mathrm{~min}$. Then the cells were washed and stained with fluorescein isothiocyanate-coupled goat anti-mouse $\mathrm{Ig} \mathrm{F}\left(\mathrm{ab}^{\prime}\right)_{2}(70 \mathrm{\mu g} / \mathrm{ml}$ ) and analyzed by a cytofluorograph (Ortho Diagnostic Systems, Westwood, Massachusetts). $\quad$ feells $\left(10^{4}\right.$ per well) were cultured in the presence of MAb (500 $\mathrm{ng} / \mathrm{ml}$ ) for 24 hours and labeled with $\left[{ }^{3} \mathrm{H}\right]$ thymidine for 2 hours before harvest; the data represent the mean of duplicate cultures with a variation of less than $5 \%$. \$Bone marrow cells isolated from the patients were morphologically $>95 \%$ blasts and showed the following phenotype: pre T-ALL, cytoplasmic CD3 $3^{+}, \mathrm{CD}^{+}, \mathrm{CD7}^{+}$ CD $34^{+}, \mathrm{Tdt}^{+}, \mathrm{CD}^{-}$, surface $\mathrm{CD} 3^{-}, \mathrm{CD}^{-}$, and $\mathrm{CD} 8^{-} ; \mathrm{T}-\mathrm{AlL}_{\mathrm{CL}} 2^{+}$, cytoplasmic $\mathrm{CD} 3^{+}, \mathrm{CD}^{+}, \mathrm{CD}^{+} 7^{+}$and $\mathrm{Tdt}^{+}$, surface $\mathrm{CD}^{-}, \mathrm{CD}^{-}, \mathrm{CD}^{-}$, and $\mathrm{CD} 34^{-}$; common-ALL $\mathrm{CD} 10^{+}, \mathrm{CD}^{+} 9^{+}, \mathrm{CD}_{22}{ }^{+}, \mathrm{CD}^{+} 4^{+}, \mathrm{CD}^{-} 0^{-}$. The effect of anti-APO-1 on these leukemic cells was not tested, because they died under normal culture conditions. IIPeripheral blood mononuclear cells (PBMC) from healthy volunteers were isolated by Ficoll Paque (Pharmacia Inc. Uppsala, Sweden) density centrifugation. Adherent cells were removed by adherence to plastic culture vessels overnight. T cells were isolated from PBMC by rosetting with 2 amino-ethylisothyouronium-bromide (AET)-treated sheep red blood cells as described (20). Freshly prepared resting T cells $\left(2 \times 10^{6}\right.$ per milliliter; $96 \% \mathrm{OKT}^{+} 1^{+}, 1 \%$ $\left.\mathrm{Tac}^{+}\right)$were activated with phytohemagglutinin-M $(50 \mu \mathrm{g} / \mathrm{ml})$ and PMA $(10 \mathrm{ng} / \mathrm{ml}$ ) (Sigma Chemical Co., Munich, FRG). Two, 7 , and 12 days later the T cells were fed with 20 to $30 \mathrm{U} / \mathrm{ml}$ of recombinant human interleukin-2 (20 to $30 \mathrm{U} / \mathrm{ml})$. T cells $\left(5 \times 10^{5}\right.$ per milliliter) activated for 12 days $\left(90 \% \mathrm{OKTll}^{+} ; 60 \% \mathrm{Tac}^{+}\right)$were cultured in the presence of FII23 or anti-APO-l $(1 \mu \mathrm{g} / \mathrm{ml})$ in triplicates for 24 hours and then labeled with $\left[{ }^{3} \mathrm{H}\right]$ thymidine for a further 17 hours (see legend to Fig. 2). $\quad$ Resting B cells $\left(35.8 \% \mathrm{CD}^{2} 9^{+}\right)$were isolated by two rounds of rosetting as above, followed by separation via a Sephadex G-10 column as described (21). For activated B cells, PBMC were adjusted to $2 \times 10^{6}$ cells per milliliter and cultured in the presence of pokeweed mitogen at $10 \mu \mathrm{g} / \mathrm{ml}$ (Serva, Heidelberg, FRG) for 6 days. Dead cells and T cells were then eliminated by rosetting with AET-treated sheep red blood cells and subsequent centrifugation over Ficoll Paque. The interphase cells were used as activated B cells (84\% $\operatorname{sIgM}^{+}$).

MAb therapies. In other therapy schedules, however, MAbs are injected repeatedly (13). In our experiments regrowth of the $\mathrm{BJAB}$ tumor was observed in three of the ten mice in which tumor regression had been observed (Fig. 3). Regrowth was observed at 
the margin of the original tumor approximately 3 months after the initial macroscopic tumor regression. One of these tumors was removed and found to express APO-1 by immunofluorescence and to be sensitive to anti-APO- 1 in vitro at a MAb concentration similar to the original in vitro $B J A B$ tumor cell line (Table $\mathbf{1}$ ).

To determine the histology of the regressing $\mathrm{BJAB}$ tumors we prepared thin sections of tumors from MAb-treated $n u / n u$ mice. Ten days after intravenous injection of FII20, BJAB appeared as a solid tumor composed of densely packed large blasts with numerous mitoses, some tumor giant cells, and rare apoptotic figures (Fig. $4 \mathrm{~b}$, left panel). The tumor was penetrated by host vessels. In contrast, almost all remaining BJAB cells of mice treated with anti-APO-1 (Fig. 4b, right panel) showed severe cytopathic changes including nuclear pycnosis and cellular edema most pronounced in perivascular microareas. These morphological changes are characteristic of apoptosis.

Taken together, these data strongly suggest that apoptosis is induced by anti-APO1 and is the mechanism of death and regression of BJAB tumor cells in vivo. The fact that FII20, which strongly binds to the cell surface of $\mathrm{BJAB}$ tumor cells, did not cause regression of $\mathrm{BJAB}$ also precludes the possibility that killer cells or complement that might have bound to anti-APO-1 may have been involved in the growth inhibition and tumor regression.

We showed that anti-APO-1 specifically blocked growth and triggered programmed cell death (apoptosis) of a set of activated normal lymphocytes and cells from malignant lymphocyte lines after binding to the cell surface protein antigen APO-1. Recently, it has been shown that anti-CD3 induces apoptosis of immature thymocytes in vitro (14). Therefore, it has been suggested that CD3-triggered apoptosis might be responsible for negative selection of $\mathrm{T}$ cells in the thymus. Since APO-1 is expressed on mature activated lymphocytes, additional experiments will be needed to determine whether the antigen might play a similar role in the downregulation of the immune response and be involved in selection and elimination of lymphocytes. It has previously been shown that LT, TNF, and killer cells with their effector molecules induce apoptotic cell death (15). As anti-APO-1 also induces apoptosis a number of possibilities might be considered for the physiological role of the APO-1 antigen. APO-1 might be a receptor for cytotoxic molecules or for autocrine growth factors. Alternatively, it could be a molecule essential for vertical or lateral growth signal transduction. Thus, anti-APO-1 might trigger receptors for lytic molecules or block receptors for growth signals.

Apoptosis is found in all tissues and also in cells from lower organisms (16). It is conceivable, therefore, that several distinct cell surface antigens with a different tissue distribution are involved in the induction of apoptosis. Elucidation of the structure of APO-1, its possible connection to the cytoskeleton and the molecular events following anti-APO-1 binding might resolve some of these issues.

Our data might also have clinical relevance. APO-1 was found on some lymphoid tumor cells freshly isolated from patients. Thus, anti-APO-1 might be useful as a diagnostic tool to define subsets of normal and malignant lymphocytes. In addition, induction of apoptosis may have implications for anti-tumor therapy. Antibodies have frequently been used as heteroconjugates with toxins or drugs to destroy tumor cells (17). Our data, however, show that $\mathrm{MAb}$ alone can be lethal to target cells. Anti-APO-1 and related MAbs might, therefore, be considered for ex vivo or in vivo therapy, under conditions where reactivity with vital normal cells can be excluded or tolerated. Finally, the molecular investigation of cell death induced by anti-APO-1 might lead to a general understanding of apoptosis. In this case, the use of modified or normal physiological ligands to the cell surface antigen initiating apoptosis or of chemicals interfering with the apoptotic signal might be envisaged.

\section{REFERENCES AND NOTES}

1. E. Duvall and A. H. Wyllie, Immunol. Today 7, 115 (1986).

2. A. H. Wyllie, J. F. R. Kerr, A. R. Currie, Int. Rev Cytol. 68, 251 (1980).

3. $\mathrm{BAL} / \mathrm{c}$ mice were immunized once per week over a 4-week period by intraperitoneal injection of $1 \times 10^{7}$ SKW6.4 cells. Four days after the last injection, spleen cells from immunized animals were fused with the P3.X63.Ag8.653 myeloma [G. Köhler and C. Milstein, Nature 256, 495 (1975)]. Twelve days after fusion culture supernatants from wells positive for growth were tested for their ability to inhibit growth of SKW6.4 cells. Hybridomas that produced blocking MAbs were cloned three times by limiting dilution at a concentration of 0.5 cells per well. MAbs were purified from serum-free culture supernatant by means of a protein A-Diasorb column (Diagen, Düsseldorf, FRG). Bound MAbs were eluted with $0.1 M \mathrm{NaCl}$ and $0.1 M$ glycine, $p \mathrm{H}$ 2.8, dialyzed against phosphate-buffered saline and sterilized. The isotype of the MAbs was determined by enzyme-linked immunosorbent assay [S. Kiesel, et al., Leuk. Res. 11, 1119, 1987) with isotypespecific goat anti-mouse Ig that had been conjugated with horseradish peroxidase (Dunn, Asbach, FRG).

4. Affinity and number of anti-APO-l binding sites per cell were determined by Scatchard analysis as described [I. von Hoegen, W. Falk, G. Kojouharoff, P. H. Krammer, Eur. J. Immunol. 19, 329 (1989)] Briefly, MAbs were iodinated by the IODO-Gen method [P. J. Fraken and J. C. Speck, Biochem. Biophys. Res. Commun. 80, 849 (1980)]. Aliquots of $5 \times 10^{5}$ cells were resuspended in $200 \mu \mathrm{l}$ of culture medium containing $0.1 \% \mathrm{NaN}_{3}$ and different con- centrations of ${ }^{125} \mathrm{I}$-labeled MAbs. After incubation at $4^{\circ} \mathrm{C}$ for 4 hours, two $95-\mu$ l portions were removed and centrifuged as described above by von Hoegen et al.

5. A. H. Wyllie, Nature 284, 555 (1980)

6. Monoclonal anti-CD19 (HD37) and anti-CD22 (HD39) were kindly provided by B. Dörken (Policlinic of the University, Heidelberg, FRG) and monoclonal anti-CD20 by G. Moldenhauer (IV Leukocyte typing workshop and conference, Vienna, Austria, 1989), respectively. The 18 nonbinding and 9 binding MAbs of the IgG 3 isotype (tested by immunofluorescence on SKW6.4 cells) and the MAbs directed against MHC class II, IgM, and SKW6.4 Ig idiotypes were raised in our own laboratory.

7. The kinetics of membrane blebbing induced by anti-APO-1 (within $30 \mathrm{~min}$; Fig. 2a) was not influenced by the presence of $10 \mathrm{mM}$ EDTA or EGTA. In addition, endonuclease-mediated DNA fragmentation induced by anti-APO-1 was not in hibited by the $\mathrm{Ca}^{2+}$ channel blockers Furamicin ( 50 $\mu M)$ or Nifedipin $(50 \mu M)$.

8. When ${ }^{51} \mathrm{Cr}$-labeled SKW6.4 cells were incubated with anti-APO-1 $(1 \mu \mathrm{g} / \mathrm{ml})$ for $2,4,8$, and 24 hours, the specific ${ }^{51} \mathrm{Cr}$ release $[R$. C. Duke, $\mathbf{R}$. Chervenak, J. J. Cohen, Proc. Natl. Acad. Sci. U.S. A. 80,6361 (1983)] was found to be $2.9 \%, 7.6 \%$, $21.3 \%$, and $32.5 \%$, respectively. Trypan blue uptake was measured at the same time points: $2.5 \%, 4.7 \%$, $10.6 \%$, and $73.6 \%$, respectively, of the cells were trypan blue-positive. In contrast, 2 hours after the addition of MAbs, plus complement the specific ${ }^{51} \mathrm{Cr}$ release was $108.7 \%$ and $92.7 \%$ of the cells stained with trypan blue.

9. Two hours after addition of MAbs $(1 \mu \mathrm{g} / \mathrm{ml})$ the genomic DNA of each tumor line was isolated and analyzed on agarose gels as described (Fig. 2) Inhibition of $\left[{ }^{3} \mathrm{H}\right]$ thymidine uptake by anti-APO-1 was paralleled by fragmentation of the genomic DNA. This was not observed after treatment with control MAb (I3B1).

10. Activated $B$ cells $\left(10^{6}\right.$ per milliliter) were incubated in the presence of MAb FII23 or anti-APO-1 at 1 $\mu \mathrm{g} / \mathrm{ml}$. After 3 days the culture supernatants were collected and the IgM concentration measured with a human IgM-specific ELISA containing HRPOconjugated goat anti-human IgM (Medac, Hamburg, FRG). IgM secretion after treatment with FII 23 or anti-APO-1 was 2100 and $550 \mathrm{ng} / \mathrm{ml}$, respectively.

11. OCI-LYl was obtained from $\mathrm{H}$. Messner, Ontario Cancer Institute, Toronto, Canada.

12. D. Pressman et al, Cancer Res. 17, 845 (1957).

13. S. L. Brown et al., Blood 73, 651 (1989).

14. C. A. Smith et al., Nature 337, 181 (1989).

15. D. S. Schmid, J. P. Tite, N. H. Ruddle, Proc. Natl. Acad. Sci. U.S. A. 83, 1881 (1986); G. B. Dealtry, M. S. Naylor, W. Fiers, F. R. Balkwill, Eur. J. Immunol. 17, 689 (1987); M. M. Don et al., Aust. J. Exp. Biol. Med. Sci. 55, 407 (1977); C. J. Sanderson, Biol. Rev. 56, 153 (1981); J. H. Russel and C. B. Dobos, J. Immunol. 125, 1256 (1980); D. M. Howell and E. J. Martz, Immunology 140, 689 (1988); J. C. Hiserodt, L. J. Britvan, S. R. Tag Targan, J. Immunol. 129, 1782 (1982); J. D.-E. Young and C.-C. Liu, Immunol. Today 9, 140 (1988).

16. F. Giorgi and P. J. Deri, Embryol. Exp. Morphol. 35, 521 (1976).

17. E. S. Vitetta et al., Science 219, 644 (1983).

18. V. K. Laemmli, Nature 277, 680 (1970).

19. The CCRF-CEM.S2 subclone was obtained by cloning cells under limiting dilution conditions from the CCRF-CEM T cell line at one cell per well in 96well microtiter plates. CCRF-CEM.S2 was selected because of its high sensitivity to programmed cell death induced by anti-APO-l $(500 \mathrm{ng} / \mathrm{ml})$ as measured by microscopic inspection in a 4-hour culture.

20. M. Madsen et al., J. Immunol. Methods 33, 323 (1980); M. A. Pellegrino et al., Clin. Immunol. Immunopathol. 3, 324 (1975).

21. T. R. Jerrells, J. H. Dean, G. L. Richardson, D. B. Herberman, J. Immunol. Methods 32, 11 (1980).

22. We thank K. Hexel, J. Köllner, R. Kühnl, C. Mandl, and W. Müller for excellent technical assistance; $H$. Sauter for excellent secretarial assistance; G. Hämmerling and G. Moldenhauer for their criticism; B. 
Dörken and G. Moldenhauer for providing MAbs, and Dr. H. Messner for providing tumor cells. We also thank D. Scheppelmann and H.-P. Meinzer for the computerized image analysis of normal and apoptotic cells. Supported by grants from the Bundesministerium für Forschung und Technolo- gie, Bonn, the Ministerium für Wissenschaft und Kunst, Stuttgart, and the Tumor Center Heidelberg/Mannheim, FRG. A.M.J.P. was supported by the Boehringer Ingelheim Fonds, Stuttgart, FRG.

3 February 1989; accepted 19 May 1989

\section{The Reservoir for HIV-1 in Human Peripheral Blood Is a T Cell That Maintains Expression of CD4}

\author{
Steven M. Schnittman, ${ }^{*}$ Miltiades C. Psallidopoulos, \\ H. Clifford Lane, Louis Thompson, Michael Baseler, \\ Ferdinand Massari, Cecil H. Fox, Norman P. Salzman, \\ ANTHONY S. FAUCI
}

Human immunodeficiency virus type 1 (HIV-1) selectively infects cells expressing the CD4 molecule, resulting in substantial quantitative and qualitative defects in $\mathrm{CD4}^{+} \mathrm{T}$ lymphocyte function in patients with acquired immunodeficiency syndrome (AIDS). However, only a very small number of cells in the peripheral blood of HIV-1-infected individuals are expressing virus at any given time. Previous studies have demonstrated that in vitro infection of $\mathrm{CD4}^{+} \mathrm{T}$ cells with HIV-1 results in downregulation of CD4 expression such that CD4 protein is no longer detectable on the surface of the infected cells. In the present study, highly purified subpopulations of peripheral blood mononuclear cells (PBMCs) from AIDS patients were obtained and purified by fluorescence-automated cell sorting. They were examined with the methodologies of virus isolation by limiting dilution analysis, in situ hybridization, immunofluorescence, and gene amplification. Within PBMCs, HIV-l was expressed in vivo predominantly in the $\mathrm{T}$ cell subpopulation which, in contrast to the in vitro observations, continued to express CD4. The precursor frequency of these HIV-1-expressing cells was about $1 / 1000 \mathrm{CD4}^{+} \mathrm{T}$ cells. The $\mathrm{CD4}^{+} \mathrm{T}$ cell population contained HIV-I DNA in all HIV1-infected individuals studied and the frequency in AIDS patients was at least 1/100 cells. This high level of infection may be the primary cause for the progressive decline in number and function of $\mathrm{CD4}^{+} \mathrm{T}$ cells in patients with AIDS.

$\mathrm{T}$ HE HUMAN IMMUNODEFICIENCY virus type 1 (HIV-l), the etiologic agent of the acquired immunodeficiency syndrome (AIDS), selectively infects cells expressing the $\mathrm{CD} 4$ molecule, including $\mathrm{T}$ lymphocytes and cells of the monocyte/macrophage lineage (1). In vitro infection of cells with HIV-l results in a decreased expression of the CD4 molecule on the surface of the infected cells (2).

Patients with AIDS have severe depression of the normal cell-mediated immune mechanisms that is partially attributed to the considerable depletion of CD4 lymphocytes (3). Despite this, examination of cells from lymph nodes and peripheral blood from patients with AIDS and AIDS-related complex (ARC) has revealed a very low frequency of viral RNA synthesis, generally occurring in $1 / 100,000$ to $1 / 10,000$ of total mononuclear cells (4). However, it is possible that a larger proportion of cells may be latently infected (containing proviral DNA but not expressing viral mRNA or protein). Until the development of gene amplification [polymerase chain reaction (PCR)] methodology $(5,6)$, HIV-1-infected cells not expressing virus were not readily detectable by available techniques.

In the present study, blood was obtained from HIV-1 culture-positive patients with AIDS either directly in heparinized syringes or via apheresis and subjected to FicollHypaque separation (7). First, peripheral blood mononuclear cells (PBMCs) from patients were stained with fluorescein isothiocyanate (FITC)-conjugated antibody to $\mathrm{CD} 3$ and sorted by a fluorescence-activated cell sorter (FACS) into $\mathrm{CD3}^{+}$and $\mathrm{CD}^{-}$ populations. Sorted cells were cocultivated with an excess of normal phytohemagglutinin (PHA)-stimulated blast cells and we determined the time to peak viral expression, a highly consistent and reproducible parameter of viral expression. A predominance of HIV-l expression in the $>98 \%$ enriched $\mathrm{CD}^{+}$population, as determined by the time to peak syncytia formation (Fig. lA) and reverse transcriptase (RT) activity (Fig. 1B), was seen. Similar results were obtained in seven additional AIDS patients. Delayed expression of HIV-l in cells that were initially $99 \% \mathrm{CD}^{-}$cells (Fig. 1B) was due to outgrowth of the few contaminating $\mathrm{CD}^{+}$cells. Phenotypic analysis of noncocultivated enriched $\mathrm{CD3}^{-}$cells grown under the same conditions revealed that 35 to $65 \%$ of the cells were $\mathrm{CD3}^{+}$by day 10 in culture.

In the second series of experiments, PBMCs from AIDS patients were doublestained with FITC-conjugated anti-CD3 and anti-CD4 and sorted by FACS into $\mathrm{CD3}^{+} / \mathrm{CD}^{+}$and $\mathrm{CD}^{+} / \mathrm{CD}^{-}$populations. These sorted cells were cocultivated with an excess of normal PHA-stimulated blast cells and showed a predominance of HIV- 1 expression in the highly enriched (98 to $99 \%) \mathrm{CD}^{+} \mathrm{T}$ cell population as determined by the time to peak syncytia formation (Fig. 1C) and RT activity (Fig. ID). Similar results were obtained in seven additional AIDS patients. The phenotypic analysis of freshly sorted $\mathrm{CD}^{+} / \mathrm{CD}^{+}$cells revealed a greater than 98 to $99 \% \mathrm{CD}^{+}$ purity in most experiments when stained with the monoclonal antibody to Leu $3 a$. Again, the delayed expression of HIV-1 in cells that were initially $99 \% \mathrm{CD}^{-}{ }^{-}$(Fig. ID) was most likely due to outgrowth of a few contaminating $\mathrm{CD}^{+} \mathrm{T}$ cells. Phenotypic analysis of non-cocultured enriched $\mathrm{CD}^{-} \mathrm{T}$ cells grown under the same conditions revealed that 30 to $55 \%$ of the cells were $\mathrm{CD}^{+}$by day 10 in culture.

In situ hybridization for HIV-1 viral RNA was then performed at time zero on the highly enriched $\mathrm{CD}^{+} / \mathrm{CD}^{+}{ }^{+}$and $\mathrm{CD}^{+} / \mathrm{CD}^{-}{ }^{-}$-sorted PBMCs. There was a predominance of viral expression in the $\mathrm{CD}^{+} \mathrm{T}$ cell population at a frequency of about $1 / 1000$ cells in four AIDS patients $(\bar{X}$ \pm SEM per 1000 cells was $0.95 \pm 0.21$ ) (Fig. 2A). This is in comparison to a level of viral expression in the $\mathrm{CD} 4^{-} \mathrm{T}$ cell population of $<1 / 100,000$ cells (Fig. 2B), which is equivalent to background signal in controls. The frequency of in situ-positive $\mathrm{CD}^{+} \mathrm{T}$ cells remained unchanged in three of the patients reexamined at 6 to 12 months after the initial studies.

Indirect immunofluorescence studies for HIV-1 viral antigens was also performed at time zero on highly enriched $\mathrm{CD}^{+} / \mathrm{CD}^{+}$. and $\mathrm{CD3}^{+} / \mathrm{CD}^{-}{ }^{-}$-sorted PBMCs. These demonstrate a predominance of viral expression in the $\mathrm{CD}^{+} \mathrm{T}$ cell population at a frequency of about $1 / 1000$ cells in four AIDS patients $(\bar{X} \pm$ SEM per 1000 cells was $1.10 \pm 0.35$ (Fig. 2C). This is in comparison to a level of viral expression in the CD4 ${ }^{-} T$ cell population of $<1 / 10,000$ cells

S. M. Schnittman, H. C. Lane, F. Massari, C. H. Fox, A. $S$. Fauci, Laboratory of Immunoregulation, National Institute of Allergy and Infectious Diseases, National Institutes of Health, Bethesda, MD 20892.

M. C. Psallidopoulos, L. Thompson, N. P. Salzman, Division of Molecular Virology and Immunology, Georgetown University School of Medicine, Washington, DC 20007.

M. Baseler, Program Resources, Incorporated, Frederick, MD 21701

*To whom correspondence should be addressed. 